\title{
SLOVAČKI JEZIČKI ZAKONI POSLE 1989. GODINE
}

Cilj ovog rada je prikaz slovačkih jezičkih zakona u istorijskom i sociolingvističkom kontekstu u periodu od 1989. godine do danas, kao i analiza restriktivnih elemenata ovih zakona i njihov razvoj. Rad će ispitati uticaj koji su ovi zakoni imali na jezike nacionalnih manjina kao i na govornike većinskog, slovačkog jezika. Posebna pažnja će biti posvećena odnosu slovačkih istaknutih lingvista prema Zakonu o državnom jeziku.

Ključne reči: jezičko zakonodavstvo, jezički zakoni, restriktivnost, Slovačka, jezici nacionalnih manjina.

This work aims to show the development of Slovak language legislation in the historical and sociolinguistic context after 1989. At the same time, this paper points to its restrictive elements and their development. The paper will examine the impact these laws have had on minority languages and speakers of the Slovak language as well. Particular attention will be given to the attitude of prominent Slovak linguists towards the Act on the State Language of the Slovak Republic.

Key words: language legislation, language laws, restrictiveness, Slovakia, minority languages.

U srednjoj i istočnoj Evropi je jezik jedan od osnovnih elemenata koji definišu etničke grupe (People i dr 2010: 389), zbog čega je jezička politika veoma važan element u procesu stvaranja identiteta novonastalih država. Ona se u multietničkim državama u najvećoj meri konkretizuje $u$ formi raznovrsnih zakonodavnih mera koje bi trebalo da potvrde suverenitet većinske etničke grupe. Jezik, zato, zbog ovako definisanih odnosa postaje izuzetno važan činilac u političkom sistemu ovih država.

Odnos između dominantne (većinske) jezičke grupe (službeni ili državni jezik) i ostalih jezičkih grupa (jezici pripadnika nacionalnih manjina) definiše jezičko zakonodavstvo kao deo jezičke politike koju određujemo kao totalitet ideja, zakona, izmena, pravila i prakse koji za cilj imaju planiranu promenu u okviru društva, određene grupe ili sistema (Kaplan i dr. 1997: 11). Jedan od istaknutih slovačkih lingvista, Juraj Dolnjik (Juraj Dolník), jezičku politiku vidi kao „súhrn aktivít, ktorými sa regulujú podmienky na fungovanie jazykov a jazykových variet koexistujúcich $\mathrm{v}$ danom politickom útvare" (Dolník 2010: 248). Ulogu jezičkih zakona je Venecijanska komisija, čija će uloga biti predstavljena u kasnijoj fazi rada, objasnila ovako:

Ochrana a podpora úradného jazyka štátu sú legitímnym záujmom, ktorý majú mnohé európske štáty spoločný. Použivanie štátneho jazyka sleduje niekol'ko legitímnych cielov: v prvom rade chráni verejný poriadok tým, že štát má na svojom územi prístup $k$ nevyhnutným informáciám a komunikácii, môže v prípade potreby za-

${ }^{1}$,skup aktivnosti pomoću kojih se regulišu uslovi za funkcionisanje jezika i jezičkih varijeteta koji koegzistiraju u određenom prostoru“ 
siahnut' a niest' zodpovednost'. Je zárukou rozvoja identity spoločenstva daného štátu a zabezpečuje vzájomnú komunikáciu medzi základnými zložkami obyvatel'stva a $v$ rámci nich. Bráni tomu, aby boli občania vystavení diskriminácii pri uplatňovaní svojich základných práv v oblastiach, kde osoby patriace $k$ národnostným menšinám majú väčšinové postavenie ${ }^{2}$ (Benátska komisia 2010: 27).

Važnost i karakter jezičke politike je za Čehoslovačku od njenog nastanka 1918. godine bio izuzetno veliki. Takozvani Manji senžermenski ugovor (Menšia saintgermainská zmluva) koji su predstavnici Čehoslovačke potpisali 19. septembra 1919. godine ih je obavezivao da, ukoliko bude određen neki službeni jezik (langue officielle) pripadnicima nacionalnih manjina u administrativnim jedinicama u kojima predstavljaju značajan deo (značný zlomok) stanovništva obezbede mogućnost da svoj jezik upotrebljavaju u službenoj komunikaciji i u sudskim procesima. Jezički zakon iz 1920. godine je pomenuti „značajan deo“ kvantitativno definisao - određena je granica od $20 \%$ pripadnika određene nacionalne manjine na teritoriji pojedinačne administrativne jedinice za ostvarivanje prava na upotrebu svog jezika u službenoj komunikaciji i pred sudovima. Ovaj zakon će u velikoj meri uticati na formu i karakter jezičkih zakona u Slovačkoj posle 1989. godine na taj način što će autori zakona iz devedesetih godina zadržati spomenutu granicu od $20 \%$ kao i nedefinisanu terminologiju. U Ćehoslovačkoj su se od spomenutog prvog jezičkog zakona iz 1920. godine svi ostali zakoni upravljali prema jednoj velikoj jezičkoj zajednici; do Drugog svetskog rata su to bili Nemci, posle drugog svetskog rata i proterivanja Nemaca su to bili Mađari. Danas mađarska nacionalna manjina predstavlja 8,5\% stanovništva (Sčítanie 2011) na jugu Slovačke. Popis stanovništva je vrlo važan element za određivanje jezičke politike i zakonodavstva, pošto se na osnovu tih rezultata određuje status jezika nacionalne manjine u određenoj jedinici lokalne samouprave jedne države.

Jezički zakoni mnogo govore o odnosu države prema manjinama. Ukoliko su restriktivni, postoji mogućnost da značajno naruše odnose između etničkih grupa u okviru jedne države. Na karakter politike jedne države prema govornicima manjinskih jezika utiče mnogo faktora. Ukoliko autori zakona imaju nameru da ograniče njihova prava ili svesno ostave prostor za njihovu asimilaciju, postoji mogućnost da se te jezičke grupe zatvore i postanu destruktivni faktor u političkom sistemu jedne države. Zato je u procesu nastajanja jezičkog zakona važan svaki element: konsultovanje predstavnika manjinskih jezičkih grupa, jasne i precizne formulacije odredbi kao i spremnost na reviziju pristupa.

Period posle 1989. godine i pada totalitarnog komunističkog režima karakterizuje obnovljeno interesovanje za rešavanje pitanja nacionalnih manjina i njihovih jezika u Slovačkoj koje do tada nije bilo regulisano dovoljno precizno i jasno ${ }^{3}$. Nezavisna

${ }^{2}$ Zaštita službenog jezika države je legitimni interes zajednički za mnoge evropske države. Upotreba državnog jezika ostvaruje nekoliko legitimnih ciljeva: pre svega štiti javni red u zemlji zbog činjenice da na svojoj teritoriji ima na raspolaganju važne informacije, i u slučaju kada je to potrebno može da interveniše i da za to snosi odgovornost. Ona je garant razvoja identiteta društva određene države i obezbeđuje komunikaciju između osnovnih elemenata društva. Štiti građane od diskriminacije prilikom ostvarivanja svojih elementarnih prava u delovima zemlje u kojima pripadnici nacionalnih manjina čine većinu.

${ }^{3}$ Upotrebu manjinskih jezika u službenoj komunikaciji su u periodu od 1948. do 1989. reguli- 
Slovačka od 1. januara 1993. godine predstavlja dobar primer koji dokumentuje važnost jezika manjina u političkom sistemu novih država. Neprestani sukobi i nesporazumi na relaciji slovačka politička elita-predstavnici mađarske nacionalne manjine su prikazali pravi karakter i obim ovog problema. Kada su 1992. godine Slovaci rešili da napuste zajedničku državu sa Česima, njihovi političari (pre svega nacionalistički orijentisani) su pronašli novog (starog) suparnika - Mađare, koji su u određenim oblastima južne Slovačke činili većinsko stanovništvo. U Slovačkoj je jezička politika od tog trenutka imala vrlo važnu ulogu: služila je kao kamen temeljac za stvaranje nacionalnog identiteta države zasnovane na nacionalnom principu (preambula Ustava Slovačke Republike počinje rečima „Mi, narod slovački“, iako su predstavnici mađarske manjine zahtevali formulaciju „Mi, građani Slovačke Republike“). Češki istoričar Jan Rihlik (Jan Rychlík) smatra da je slovačka javnost restriktivne jezičke zakone videla kao neminovne mere potrebne za konsolidaciju novonastale države, dok su za mađarsku manjinu oni predstavljali napad na njihov jezik, kulturu i slobodu (Rychlík 2002:141).

Slovačka politički vrh je rešavanje pitanja statusa slovačkog jezika u odnosu na ostale (manjinske) jezike počeo da rešava još pre raspada Čehoslovačke. Zakon usvojen 1990. godine (Zákon o úradnom jazyku SR) nije zadovoljio nikoga ${ }^{4}$. Iako u njemu (još uvek) nije upotrebljena sintagma „državni jezik“ (štátny jazyk), ipak je sadržao nekoliko spornih, nejasnih i potencijalno opasnih elemenata po jezike nacionalnih manjina.Već u prvom članu ih je bilo nekoliko. Slovački jezik je označen kao službeni jezik na teritoriji Slovačke Republike (prvi stav), koji će u okviru takvog statusa pomoći u razvoju kulture i demokratije, kao i boljim odnosima sa nacionalnim manjinama. Najvažniji nedostatak je činjenica da je definicija pojma „,službeni jezik“" nedostajala, što u velikoj meri komplikuje analizu. Jezički zakon iz 1990. godine je sadržajem trećeg člana izazvao revolt pripadnika nacionalnih manjina, jer je u četvrtom stavu odredio službeni jezik kao jedini koji je moguće koristiti prilikom označavanja naziva mesta, opština, ulica, trgova i ostalih geografskih naziva. Ovoga puta su neprecizne odredbe zakona iskoristili pripadnici nacionalnih manjina. Pošto ovim članom nije eksplicitno zabranjena upotreba jezika nacionalnih manjina u tom svojstvu, izdejstvovali su usvajanje zakona (ali tek 1994. godine), koji je dozvoljavao dvojezično obeležavanje svih geografskih naziva u opštinama u kojima je udeo manjinskog stanovništva premašivao 20 procenata (Hacker 2014: 70).

Šesti član je bio najvažniji deo ovog zakona za nacionalne manjine, jer je definisao uslove pod kojima su one mogle da koriste svoj jezik u službenoj komunikaciji. $\mathrm{U}$ administrativnim jedinicama u kojima je broj pripadnika nacionalne manjine činio najmanje 20 posto ukupnog broja stanovnika, ta nacionalna manjina je mogla da koristi svoj jezik u službenoj komunikaciji. Kao i u prethodnim slučajevima, ovaj član je sadržao i problematični (nedefinisani) deo. Ovaj put je veliki nedostatak predstavljala odredba prema kojoj službenici u lokalnim samoupravnim organima nisu morali

sala tri Ustava iz 1948, 1960. i 1968. godine.

${ }^{4}$ Matica slovačka (uz razne desničarske organizacije i političke partije) je u prvoj polovini 1990. godine organizovala nekoliko skupova na kojima je zahtevano da slovački jezik postane jedini službeni jezik na teritoriji Slovačke. Prilikom usvajanja Zakona u skupštini 25. oktobra 1990. godine je ispred zgrade ove institucije došlo do konflikta između pristalica predloga Matice slovačke i aktivista grupe Human koji su pozivali na toleranciju (Rychlík 2002: 144). 
da znaju jezik nacionalne manjine koja je u administrativnoj jedinici u kojoj su vršili svoju funkciju premašivala 20 procenata ukupnog broja stanovnika.

Na opravdana pitanja političkih predstavnika nacionalnih manjina zašto je odabrana granica od dvadeset posto i zašto službenici nisu morali da znaju jezik nacionalne manjine u opštinama u kojima je ta nacionalna manjina imala pravo na upotrebu svog jezika u službenoj komunikaciji nije odgovoreno. I ovaj put je ostavljen prostor za potencijalnu diskriminaciju pripadnika nacionalnih manjina zbog činjenice da su službenici mogli da odbiju komunikaciju na jeziku nacionalne manjine i da kao razlog navedu ovaj član zakona koji im je dozvoljavao da ne znaju jezik nacionalne manjine koja je u određenoj jedinici samouprave imala pravo na upotrebu svog jezika.

Pad komunističkog režima je otvorio mnoga pitanja, od kojih je jedno bilo i ono koje se ticalo statusa nacionalnih manjina i upotrebe njihovih jezika. Zakon o službenom jeziku Slovačke Republike, koji je usvojen 25. oktobra 1990. godine je zapravo bio ustupak sve jačoj slovačkoj političkoj desnici, koji su autori pokušali da sakriju u nejasne i neprecizne odredbe koje bi u određenim situacijama (proizvoljnim tumačenjem) mogle da ograniče prava pripadnika nacionalnih manjina na upotrebu svog jezika u službenoj komunikaciji. Jedinu pobedu liberalnih snaga na političkoj sceni može da predstavlja činjenica da je slovački jezik još uvek definisan „samo“ kao službeni a ne državni jezik (iako je izostala definicija i ove formulacije) (Daftary i dr. 2000: 22).

Usvojen 15. novembra 1995. godine, Zakon o državnom jeziku (Zákon o štátnom jazyku) je zamenio onaj iz 1990. godine i u velikoj meri promenio položaj i prava manjinskih jezika u Slovačkoj ${ }^{5}$. Njime je ukinuta granica od najmanje dvadeset posto pripadnika nacionalne manjine u određenoj administrativnoj jedinici za upotrebu jezika te manjine u službenoj komunikaciji, dok je slovački jezik dobio status državnog jezika. Na taj način je status upotrebe jezika nacionalnih manjina ostao nedefinisan sve do zakona koji će biti usvojen tek 1999. godine. Prirodu ovog zakona je dobro pokazao i sam način njegovog usvajanja u skupštini. Zasedanje je prenosila državna televizija i svaki poslanik je morao da ustane i da glasa. Kompletna mađarska politička reprezentacija u parlamentu je glasala protiv ovog zakona (Gbúrová 2009: 76).

Uvodni deo Zakona je slovački jezik okarakterisao kao najvažniji element identiteta naroda, i što je još važnije, proglasio ga za nosioca suvereniteta Slovačke republike. Dakle, gde god se na teritoriji Slovačke nije govorio slovački jezik, ugrožen je bio njen suverenitet, što one koji govore, na primer, mađarski na ulici u gradu sa većinskim manjinskim stanovništvom, potencijalno čini građanima koji taj suverenitet narušavaju.

U prvom članu je slovački proglašen za državni jezik, pri čemu je opet izostala definicija ove sintagme. Najvažniji deo ovog člana je treći stav, kojim se odgovornost za regulisanje statusa jezika nacionalnih manjina prebacuje na poseban zakon, koji će biti usvojen tek 1999. godine (dakle, nacionalne manjine su na zakon o upotrebi svojih jezika u službenoj komunikaciji čekale četiri godine). Odsustvo zakona o jezicima nacionalnih manjina je Ustavni sud Slovačke Republike proglasio za neustavno (Orosz 1989).

\footnotetext{
${ }^{5}$ U međuvremenu je Slovačka 1. januara 1993. godine postala nezavisna država.
} 
Član broj tri u prvom stavu između ostalog navodi i „Zadovoljavajuće poznavanje“ (primeraná znalost') državnog jezika kao najvažniji kriterijum za dobijanje posla u organima lokalne samouprave. Kao i u prethodnim slučajevima, neodređenost ove formulacije je podložna različitim tumačenjima i potencijalnoj zloupotrebi. Pošto nije postojao jasan kriterijum (na primer, test kojim bi se utvrdio nivo poznavanja jezika kandidata za posao), pripadnik nacionalne manjine kojem slovački jezik nije maternji bi mogao da ostane bez posla jer nije pokazao „zadovoljavajuće poznavanje“ državnog (slovačkog) jezika. Dalje, to bi moglo da dovede do sistematskog zapošljavanja službenika koji ne govore mađarski u mestima sa mađarskom većinom, čime bi u velikoj meri komunikacija između državnih organa i pripadnika nacionalnih manjina bila otežana.

Jednako restriktivni su i treći stav četvrtog člana, kojim se dozvoljava vođenje školske dokumentacije samo na državnom jeziku, šesti stav osmog člana prema kojem svi natpisi i reklame moraju biti na državnom jeziku, pri čemu svaki tekst na stranom jeziku mora biti ispod teksta na državnom jeziku i ne sme biti u većem formatu. Zakon o državnom jeziku predviđa i kazne, pri čemu su najviše kazne predviđene za pravna lica koja krše zakon u sredstvima javne komunikacije.

Zakon o državnom jeziku iz 1995. godine je najvažniji zakonski akt o statusu većinskog jezika u Slovačkoj. Tadašnja politička elita predvođena premijerom Vladimirom Mečjarom (Vladimír Mečiar) je pokazala jasnu nameru da ograniči upotrebu manjinskih jezika (pre svega mađarskog) u svim formama. Iako je u to vreme mađarska politička reprezentacija postala važan deo političke scene, ona je i dalje bila percipirana kao potencijalni separatistički faktor (Hacker 2014: 42).. Ovim zakonom su svi pripadnici nacionalnih manjina koji su hteli da koriste svoj jezik bili dovedeni u stanje pravne nesigurnosti, koje je bitno uticalo na međuetničke odnose u Slovačkoj (Orosz 1989).

Promena odnosa prema rešavanju problema položaja manjinskih jezika je došla tek sa promenom vlasti 1998. godine, kada je režim, čiji je najreprezentativniji predstavnik bio premijer Vladimir Mečjar, smenjen. Vlada na čelu sa Mikulašom Dzurindom (Mikuláš Dzurinda) je kao prioritet odredila članstvo u Evropskoj uniji, zbog čega je bila primorana da brzo pronađe rešenje za status manjinskih jezika. Evropska unija i NATO su u julu 1997. zaključili da Slovačka ne ispunjava uslove za članstvo u ovim organizacijama. Jedan od glavnih razloga je bio i odsustvo zakona o upotrebi jezika nacionalnih manjina (Daftary i dr. 2000: 27).

Parlament Slovačke Republike je 10. jula 1999. godine usvojio Zakon o upotrebi jezika nacionalnih manjina (Zákon o používaní jazykov národnostných menšín). Slovačka je vrlo brzo bila pozvana na samit Saveta EU u Helsinkiju u decembru 1999. godine da započne pristupne pregovore sa Evropskom unijom. Uprkos tome, zakon je usvojen u lošoj atmosferi zbog odsustva javne rasprave, kao i zbog činjenice da pri sastavljanju zakona nisu konsultovani predstavnici nacionalnih manjina (Gbúrová 2009: 80). Najveća mađarska partija, Partija mađarske koalicije (Strana mad'arskej koalície) koja je u tom trenutku bila deo vlade, nije glasala za ovaj zakon. Kao glavni razlog su naveli izuzetno visoku granicu od $20 \%$ pripadnika neke manjine u određenoj administrativnoj jedinici potrebnoj za ostvarivanje svojih jezičkih prava, kao i to da se zakon bavio samo službenom upotrebom jezika (Daftary i dr. 2000: 29).

Drugi član ovog zakona je sadržao ključnu odredbu zakona, prema kojoj pripadnici nacionalne manjine imaju pravo na upotrebu svog jezika u službenoj komunika- 
ciji, ukoliko prema poslednjem popisu u toj administrativnoj jedinici čine najmanje dvadeset posto stanovništva. Zakon je, između ostalog, dozvoljavao pripadnicima nacionalnih manjina upotrebu svog jezika u službenoj komunikaciji (treći stav drugog člana), na tablama na zgradama lokalnih samouprava (peti stav drugog člana), na zasedanjima organa lokalne samouprave (prvi stav trećeg člana), kao i na tablama koje sadrže nazive mesta, ulica ili drugih geografskih naziva (prvi stav četvrtog člana). Zakon nije rešio problem upotrebe jezika manjina u sudskim procesima, već se pozivao na već postojeće zakone (prvi stav petog člana), na osnovu kojih su pripadnici nacionalnih manjina imali pravo na prevodioca, što svakako nije bilo dovoljno. Jedan od najvećih nedostataka ovog zakona jeste činjenica da i dalje nije obavezivao službenike u organima lokalne samouprave da govore jezikom nacionalne manjine $\mathrm{u}$ administrativnim jedinicama u kojima nacionalna manjina čini najmanje 20 posto stanovništva (prvi stav sedmog člana).

Iako je usvajanje ovog zakona Slovačkoj otvorilo put ka pristupnim pregovorima sa Evropskom unijom, predstavnici nacionalnih manjina nisu bili zadovoljni. Ukoliko se u obzir uzmu sve prednosti i nedostaci ovog zakona, status manjinskih jezika je zapravo bio sličan onom koji su imali pre usvajanja zakona iz 1995. godine. Vraćena je granica od 20 posto, delimično je regulisana upotreba manjinskih jezika u javnom prostoru i ukinute su sankcije za kršenje odredbi zakona iz 1995. godine (osmi član). Predstavnici mađarske manjine su zahtevali jedan širi okvir rešavanja pitanja položaja manjinskih jezika, koji bi obuhvatio kulturu, medije i upotrebu manjinskih jezika u neslužbenoj komunikaciji. Ovaj cilj je tek delimično ostvaren izmenama i dopunama zakona iz 2011. godine, kojima je procenat pripadnika nacionalne manjine na teritoriji neke administrativne jedinice potreban za ostvarivanje jezičkih prava te manjine spušten na 15 procenata (prvi stav sedmog člana).

Zakon o državnom jeziku je 1. septembra 2009. godine doživeo izmene i dopune. Restriktivni elementi su ojačani, vraćene su i kazne za kršenje odredbi koje je ukinuo Zakon o upotrebi manjinskih jezika iz 1999. godine. Konsternacija predstavnika mađarske manjine je prešla granice Slovačke i prelila se u Mađarsku, koja je preuzela ulogu zaštitnika svojih sunarodnika u susednoj zemlji. Preko deset hiljada pripadnika mađarske nacionalne manjine se 1. septembra 2009. godine okupilo na fudbalskom stadionu u znak protesta u gradu Dunajská Streda na jugu Slovačke, pri čemu je mađarskom predsedniku zabranjen ulazak na teritoriju Slovačke (BBC 2009). Slovačka je, uslovno rečeno, bila nezadovoljna primenom jezičkog zakona kada se radilo o njegovim restriktivnim elementima, dok su predstavnici manjina zahtevali još liberalnije odredbe u odnosu na one iz zakona o upotrebi manjinskih jezika iz 1999. godine (Gbúrová 2009: 104). Da bi slovačka vlada opravdala legitimnost spomenutih izmena, zatražila je mišljenje od Venecijanske komisije, koje je bilo gotovo u oktobru 2010. godine (Stanovisko Benátskej komisie z roku 2010). Predstavićemo samo najznačajnije zaključke mišljenja.

Pošto Zakon o upotrebi jezika nacionalnih manjina ima status lex specialis u odnosu na Zakon o državnom jeziku, Komisija je kao nedostatak navela činjenicu da Zakon o državnom jeziku ima nadređeni status s obzirom na činjenicu da je on daleko restriktivniji i predložila je jedinstveni, odnosno kompleksniji zakon o jeziku.

Članovi komisije su upozorili autore zakona i na formulaciju ,službena komunikacija“" (úradný styk), koja nije definisana, što u daljem procesu zaključivanja stvara 
konfuziju koja se tiče stepena slobode upotrebe manjinskog jezika u komunikaciji na radnom mestu u okviru državnih institucija.

Veliki nedostatak Zakona je prema mišljenju Komisije bila i odredba prema kojoj su školske ustanove obavezne da kompletnu školsku dokumentaciju vode i na državnom (slovačkom) jeziku. Ova odredba je zato restriktivna, jer zahteva prevođenje kompletne dokumentacije na slovački, što iziskuje dodatne finansijske troškove i veće opterećenje za zaposlene u administraciji. Komisija je predložila da se obim dokumentacije ograniči samo na najvažnije dokumente. Slične zamerke je Venecijanska komisija imala i za ograničenja koja su se ticala emitovanja televizijskog i radio programa. Pošto je, prema zakonu, svaki strani sadržaj morao da se prevede, Komisija je predložila dodatnu finansijsku pomoć za emitere.

Kao najveći problem su članovi komisije definisali status manjinskih jeziku u sudskom sistemu. Pošto su na osnovu oba zakona o jezicima pripadnici nacionalnih manjina imali samo pravo na prevodioca, Komisija je predstavnike izvršne vlasti u Slovačkoj podsetila da su se potpisivanjem Evropske povelje o manjinskim i regionalnim jezicima (što je Slovačka učinila 1995. godine) obavezali na to da pripadnicima nacionalnih manjina obezbede sudske procese i kompletnu dokumentaciju na njihovim jezicima. Naposletku, Komisija je predložila da se vrlo problematična odredba o kaznama, ukoliko već ne postoji prostor da se ona eliminiše, primenjuje samo u najekstremnijim slučajevima.

Venecijanska komisija je u svojoj analizi došla do sledećeg zaključka: iako zakon o državnom jeziku ima legalitet i legitimitet, ipak je potrebno napraviti neke suštinske izmene, koje bi smanjile represivnost i povećale pravnu sigurnost, koja bi se postigla preciznijim definicijama i formulacijama.

Dakle, moguće je zaključiti da je mišljenje stručnjaka koji su bili deo ekspertskog tima Komisije potvrdilo pravo Slovačke na jezički zakon radi legitimne odbrane nacionalnih interesa. Slovačka izvršna vlast je upozorena na mnogo nedoslednosti, nejasnosti i nepreciznosti u odredbama dva zakona koji su regulisali i regulišu upotrebu jezika u Slovačkoj, kao i na jasno ograničavanje prava nacionalnih manjina u izuzetno važnim oblastima (sudstvo, školstvo).

Posebnu celinu problematike koja se tiče slovačkih jezičkih zakona čini odnos najuglednijih slovačkih lingvista prema ovom pitanju. Spomenuti Juraj Dolnjik je u svojoj knjizi Teória spisovného jazyka iz 2010. godine autorima Zakona o državnom jeziku u najvećoj meri zamera to što su mu dodelili ulogu podizanja jezičke kulture, što je za ovog autora oblast kojom bi trebalo da se bavi Jezički institut Ljudovita Štura (Jazykovedný ústav L'udovíta Štúra) (Dolník 2010: 253). Dugogodišnji direktor ovog instituta od 1981. do 1992. godine, Jan Kačala (Ján Kačala), istaknuti naučnik u oblastima kao što su ortografija i ortoepija je 1994. godine (dakle, godinu dana pre usvajanja Zakona) napisao knjigu Slovenčina-vec politická? (Slovački jezik-političko pitanje?) u kojoj je predstavio nekoliko teza koje su konzistentne sa restriktivnom prirodom oba zakona usmerenom kako prema pripadnicima manjinskih jezika, tako i govornicima službenog, državnog odnosno većinskog jezika. Kao osnovni argument koji opravdava postojanje jednog zakona koji će slovačkom jeziku odrediti dominantnu ulogu u društvu Kačala spominje navodnu asimilaciju Slovaka na jugu Slovačke koju sprovodi mađarska manjina (Kačala 1994: 53-54) pri čemu je nuž- 
no zavođenje ,lingvističkog suvereniteta“ koji će pratiti državni suverenitet i zaštiti jezik od svih potencijalno opasnih elemenata uz nametanje standardnog jezika koji će osnažiti jedinstvo i kompaktnost jezika (Kačala 1994: 162-169, 172-176). Renomirani lingvisti kao što su Slavomir Ondrejovič (Slavomír Ondrejovič), Sibila Mislovičova (Sibyla Mislovičová) i Julija Vrabljova (Julia Vrabl’ová) u najvećoj meri putem elektronskih medija ističu stav da upotreba jezika u svim vidovima komunikacije ne bi trebalo da podleže sankcijama bilo koje vrste.

Primenjivanje Zakona o državnom jeziku u najvećoj meri sprovodi i kontroliše Ministarstvo kulture Slovačke Republike (Ministerstvo kultúry SR) koje rezultate svojih aktivnosti na ovom polju predstavlja u izveštajima svake dve godine. U poslednjem izveštaju iz 2018. godine je moguće pronaći tendencije koje pokazuju i način na koji se redukuje bogatstvo jednog jezika, ukoliko ga shvatamo kao manifestaciju jezičke varijabilnosti i raznovrsnosti (Dolník 2010: 255). Autori ovog izveštaja, između ostalog, hvale stanje u osnovnim i srednjim školama u kojima se potiskuju manifestacije dijalekatskog govora, kako kod pedagoga, tako i kod đaka. Novčane kazne su u periodu od 2015. do 2017. godine plaćale televizijske stanice i to zbog činjenice da su filmski sadržaj emitovale sa sinhronizacijom na češkom jeziku (ukupan broj kazni je šest, najviša je u iznosu od 3000 evra).

Jezičko zakonodavstvo reguliše odnose u veoma delikatnoj oblasti. Jezik je verovatno najdominantniji element identiteta etničkih grupa i zato zakoni koji definišu njegov status i upotrebu zahtevaju formulacije koje bi eliminisale svaku vrstu pravne nesigurnosti, upravo kao posledicu nepreciznih, nejasnih i dvosmislenih formulacija. Na karakter jezičkog zakona utiču mnogi faktori, od kojih su presudni oni koji se tiču političke situacije u određenoj državi. Važnost pravnog statusa jezika nacionalnih manjina je pokazao razvoj situacije u Slovačkoj posle 1989. godine i pada komunističkog režima. Desničarske političke organizacije su odmah zatražile ograničavanje prava za upotrebu manjinskih jezika, koja je bila uperena pre svega na upotrebu u neslužbenoj komunikaciji, pošto je upotreba manjinskih jezika u službenoj komunikaciji bila relativno regulisana. Zakon iz 1990. godine je odraz težnji da se izađe u susret svima: i onima koji su hteli liberalniji sistem, kao i onima koji su zahtevali ograničavanje prava pripadnika nacionalnih manjina. To je najverovatnije i jedan od razloga zbog kojih je taj zakon obilovao kontradikcijama i konfuznim formulacijama.

Zakon iz 1990. je na snazi bio do 1995. godine. U međuvremenu je Slovačka postala nezavisna zemlja. Može se konstatovati da je usvajanje Zakona o državnom jeziku iz 1995. godine bila pobeda nacionalističkih elemenata slovačke političke elite, koja je u sastavljanju zakona iskoristila sve moguće načine da obezbedi dominantnu poziciju većinskog jezika i ostavi prostor za nesigurnost govornika manjinskih jezika: nejasne formulacije, arbitrarnost i restriktivnost. Ovaj zakon je regulisanje statusa i upotrebe manjinskih jezika preneo na specijalni zakon u budućnosti, koji je usvojen tek posle smene Vladimira Mečjara i njegove politike.

Zakon o upotrebi manjinskih jezika iz 1999. godine je pokazao spremnost Slovačke Republike da postane deo evropskog sistema vrednosti u kojem su prava manjinskih jezika zaštićena. Ipak, zakon je bio površan, regulisao je samo upotrebu manjinskih jezika u službenoj komunikaciji i zato je doživeo kritiku i protivljenje političkih predstavnika manjina, koje su tvrdile da nisu konsultovane i da njihov zahtevi i primedbe nisu uzeti u obzir. Najveća vrednost ovog zakona je ukidanje kazni sadr- 
žanih u Zakonu o državnom jeziku iz 1995. godine i potrebna granica od dvadeset posto pripadnika nacionalnih manjina u okviru određene administrativne jedinice za upotrebu svog jezika u službenoj komunikaciji.

Slovačka republika je 2004. godine postala deo Evropske unije i tada se činilo da će politika prema nacionalnim manjinama pokazivati još liberlanije tendencije. Iznenađujuće izmene i dopune Zakona o državnom jeziku 2009. godine, kojom su vraćene novčane kazne i koja je radikalizovala restriktivnost pojedinih elemenata, izazvala je negodovanje mađarske manjine i dela evrospke javnosti. Venecijanska komisija je u svom mišljenju iz 2010. godine potvrdila legitimnost zakona ali i apelovala na slovačke političke predstavnike da svoje napore usmere prema sastavljanju jednog jedinstvenog i kompleksnog zakona koji bi u potpunosti eliminisao pravnu nesigurnost pripadnika nacionalnih manjina.

Ukoliko se prilikom sastavljanja zakona ne konsultuju predstavnici nacionalnih manjina (manjinskih jezika), politička elita većinskog naroda pokazuje da nije spremna da rešava probleme, već da nameće rešenja koja nisu nužno delotvorna i dobra. Iako je Slovačka Republika početkom novog milenijuma pokazala spremnost da liberalizuje svoj odnos prema nacionalnim manjinama (mađarskoj, pre svega) i njihovim jezicima, i dalje postoje retrogradne tendencije koje remete ionako nestabilne odnose sa Mađarskom i dovode do situacije u kojoj obe zemlje dolaze u poziciju da zahtevaju međunarodnu arbitražu. Od tada je moguće primetiti pozitivnije trendove u shvatanju politike prema jezicima nacionalnih manjina. Zakon o upotrebi jezika nacionalnih manjina je 2011. godine doživeo izmene i dopune, u okviru kojih je najveća promena spuštanje granice na $15 \%$ pripadnika nacionalne manjine u okviru određene administrativne jedinice za upotrebu svojeg jezika kao službenog.

Slovačka danas ima dva zakona koji regulišu status većinskog i manjinskih jezika, pri čemu je Zakon o državnom jeziku u nadređenom (lex specialis) položaju u odnosu na onaj koji reguliše status i upotrebu manjinskih jezika. To ostavlja prostor za arbitrarnost prilikom tumačenja, bez obzira na pozitivne izmene Zakona o upotrebi manjinskih jezika. Važno je napomenuti da je nadređeni Zakon o državnom jeziku zadržao gotovo sve potencijalno restriktivne elemente, koji u određenom trenutku mogu postati legitimno sredstvo za obračun ili ograničavanje sloboda za pripadnike nacionalnih manjina. Kako zaključuje Venecijanska komisija, sve dok se slovačka politička elita ne odluči za jedan sveobuhvatni i kompleksni zakon, postojaće i tenzije.

\section{Citirana literatura}

Daftary, Farimah, Kinga Gál. «The New Slovak Language Law. Internal or External Politics». ECMI Working Paper No. 4. Flensburg: European Centre for Minority Issues, 2000.

Dolník, Juraj. Teória spisovného jazyka. Veda, 2010.

Gbúrová, Marcela. Politka v jazyku jazyk v politike. Bratislava: Kubko Goral, 2009.

Hacker, Paul. Slovensko 1990-1993. Bratislava: Artforum, 2014.

Kačala, Ján. Slovenčina-vec politická. Martin: Matica slovenská, 1994.

Kaplan, Robert., Richard Baldauf. Language Planning. From Theory to Pratcice. 
Multilingial Matters, 1997.

Orosz, Ladislav. Mad'arská národnostná menšina a legisaltívne zmeny v jej postavení po roku 1989. <http://www.saske.sk/cas/archiv/4-2008/05-orosz.html> 05.02.2019.

People, James, Garrick Bailey. Humanity: An Introduction to Cultural Anthropology. Wadsworth Publishing, 2011.

Protests over Slovak language law. (2.9.2009). BBC News. Dostupno na: <http://news. bbc.co.uk/2/hi/europe/8232878.stm> [27.10.2019.]

Rychlík, Jan. Rozpad Československa. Česko-slovenské vztahy 1989-1992. Bratislava: Academic Electronic Press, 2002

Sčítanie obyvatel'ov, domov a bytov 2011. Dostupno na: <https://census2011.statistics. sk/tabulky.html> [05.02.2019.]

Stanovisko k zákonu o štátnom jazyku, Benátska komisia, 2010.

Štvrtá správa o používaní štátneho jazyka na územi Slovenskej republiky, 2018.

Zákon č. 428/1990 Zb. Slovenskej národnej rady o úradnom jazyku v Slovenskej republike.

Zákon č. 270/1995 Z.z. Národnej rady Slovenskej republiky o štátnom jazyku Slovenskej republiky.

Zákon č. 184/1999 Z.z. Národnej rady Slovenskej republiky o používaní jazykov národnostných menšín.

Zákon č. 318/2009 Z. z. Národnej rady Slovenskej republiky, ktorým sa mení a dopín̆a zákon Národnej rady Slovenskej republiky č. 270/1995 Z. Z. o štátnom jazyku Slovenskej republiky v znení neskorších predpisov a o zmene a doplnení niektorých zákonov

Zákon č. 204/2011 Z. z. Národnej rady Slovenskej republiky, ktorým sa mení a dopín̆a zákon č. 184/1999 Z. z. o používaní jazykov národnostných menšín v znení zákona č. 318/2009 Z. z. a ktorým sa menia a dopĺñajú niektoré zákony.

\section{Marko Stojanović}

\section{SLOVAK LANGUAGE LAWS AFTER 1989}

\section{Summary}

Language legislation is important because it defines the rights of minorities to use their language. This work aims to show the development of Slovak language legislation in a historical context. At the same time, this work wants to point to its restrictive elements and their development, which were influenced by language policy in Czechoslovakia from 1918 until its dissolution. Language legislation is important because it defines the rights of national minorities to use their language in the territory of a country in which another state (official) language has a dominant position.

The goal will be to analyze in detail the provisions of all language-related laws in Czechoslovakia and, in particular, in the independent Slovak Republic (from 1993). We will focus on ambiguities in legislative measures, but also on the relationship between various legislative measures that define the status and rights of members of national minorities and which, due to these features, are potentially problematic points.

Key words: language legislation, language laws, restrictiveness, Slovakia, minority languages. 